\title{
The Impact of Community Response to the Marginalization of the Existence of Indang Arts Tradition
}

\author{
Susmiarti \\ Lecturer of Sendratasik \\ Fakultas Bahasa dan Seni Universitas Negeri Padang \\ Padang, Indonesia \\ susmiartisusmiarti@yahoo.com
}

\author{
Indrayuda \\ Lecturer of Sendratasik \\ Fakultas Bahasa dan Seni Universitas Negeri Padang \\ Padang, Indonesia \\ indrayudayusuf@yahoo.co.id
}

\begin{abstract}
This article aims to analyze the responses of the people who think that the art of Indang is less competitive in the entertainment industry. As a result, Indang art is often viewed as having little feasibility to be sold in the entertainment industry. The consequence of this negative perspectives towards Indang, that the Indang existence has become more and more marginalized. This qualitative research, aimed at finding out why some indang arts traditions are not valued as having acompetitive values in the entertainment arts industry. In addition, this study useds a multidisciplinary approach to further research the sociology of dance and music anthropology, choreography, and artistic performances of the show. The result obtained from the research is that the community considers the art of Indang tradition today has lost its ability to compete with the creation that is innovative. This resulted in the marginalization of the Indang by the owners themselves such as the local people. so that local people as owners have marginalized the art of Indang. People assume that the art of Indang tradition is no longer relevant to the market's tastes and the entertainment' enthusiasts. In fact the art of Indang tradition has been increasingly abandoned by society. In turn, Indang art needs to be developed in a more innovative way.
\end{abstract}

Keywords - Indang art, marginalization, and market tastes

\section{INTRODUCTION}

Padang Pariaman District as one of the areas of government and ethnicity, located on the west coast of West Sumatra Province, has variety unique traditional arts. The arts come from the collective mind of Pariaman society such as Salawat Dulang, Ulu Ambek, Randai, and Indang art. The Indang art is generally located almost in all villages in Padang Pariaman district. The art of Ulu Ambek and Indang is a popular art for the wider community in West Sumatra and outside West Sumatra today. Ulu Ambek, Salawat Dulang, and Indang grow and develop in every nagari in the city of Padang Pariaman and Pariaman to the present day.

One of the art that developed enough until now in Padang Pariaman is Indang. Historically Indang art closely related to the growth and development of Islam in Padang Pariaman in particular and West Sumatra generally. At first this show was used as a means of developing the teachings of Islam by ulama-ulama and religious teachers in surau.

Ediwar said (2010) Indang art that originally lived and developed environment surau evolved into folk art that is performed in the fight-games, and functioned as entertainment community in various events and ceremonies, such as alek nagari, enliven ceremony batagak penghulu, batagak rumah gadang, etc.

The Indang art performance in the event crowd called alek Indang, which is usually held in the event alek nagari. Nowadays, Indang art performance is often performed by showing three groups of Indang called Indang Tigo Sandiang or Indang Tigo Jerong. These three groups perform like a race or a match, they perform by bringing various pantun-rhymes that they reef themselves, which is composed by Indang players called tukang dikia and tukang karang (author). Each group performs alternately to ask questions, answer questions, and sarcastically in the form of pantun spontaneously. For a group that is not able to answer an opponent's group questions, it will be considered defeated in the Indang show.

The Indang is a complex art, containing three elements of art of motion, music, and oral literature. According to Vortixa, O., Agustina, A., and Nursaid, N. (2012), Indang players in the show have a kick, dance, and play a musical instrument. This means that Indang art is a performing arts consisting of three elements of art in a unity of performances. Usually Indang players sit in march to form a formation like a syaf, consisting of 12 to 24 people from a group of Indang players. Referring to the flow of globalization that has spread to various sectors of community life, one of which is the arts and tourism sector. In fact, the impact of the emergence of the entertainment industry and tourism sector in West Sumatra. The growth of the 
entertainment industry, has encouraged the formation of various event organizers and art galleries that appear like mushrooms in various cities and districts in West Sumatra.

Starting from the performance industry showcase in West Sumatra, there has been a competitive competition map between traditional arts and modern art or artistic creations. Competition is based on the quality and packaging of performances, innovations and innovations in the form of performances, as well as on performance management art innovation. In addition, competition is also based on marketing innovation, and the perpetrators of the perpetrators. This means that the appearance of artist dancers and musicians also helped trigger a map of competition between the art of entertainment and traditional art in West Sumatra today. The map of the competition has begun in the early 1980s in West Sumatra to date.

Kamal (2012) said that traditional art in Padang Pariaman both Indang and Ulu Ambek has decreased activity performances. The decline in these activities has caused traditional art to be less popular and less have the opportunity to be used in various cultural events, as well as entertainment activities for the community in Padang pariaman.

Competitive competition impacts on the exclusion of traditional Minangkabau art forms, such as Traditional Indang art (Baindang). The existence of traditional Indang (Baindang) urged by the splendor and quality of artistic performances creations, such as dance creations are produced by many production houses in Pariaman City and Pariaman District. Consequently traditional Indang art lacks markets, the traditional Indang art market revolves around alek nagari events, occasionally displayed in weddings.

The existence of Indang art as a traditional art from the Pariaman region, indirectly crushed from the turbulent flow of changes to the performing arts in Pariaman. In response to the development of the performing arts, Pariaman society beg an to turn from the taste of traditional art to modernization. Because today, Pariaman people's appetite for the show is loaded with entertainment value (entertainment). In turn, the various cultural activities undertaken by the community can not be separated from the entertainment arts activities. Therefore, Indang art tradition has become a marginal art in the cultural life of Padang Pariaman community.

\section{METHOD}

This research is qualitative, qualitative data is used to inventory and analyze art of Indang tradition which is less competitive in entertainment art industry activity. In addition, this research uses a multidisciplinary approach such as the sociology of dance and anthropology of music, choreography, and artistic performances. All issues related to the public response to the performance of Indang art serve as the object of study in this study. Informant of the research is the actors and creators of art Indang, artists, some elite adat and adat stakeholders as well as community lovers and artists of Indang management.

The data were collected by observing the pattern of the work, the performance, the audience response to Indang performance, or the artist's behavior on the stage or arena. Interviews were conducted to Indang artists to obtain information on the shape and structure of the claim. While interviewing to the community to get their response about the appeal of forms and art performances Indang. The Data collection also uses recording facilities, and shooting as well as archival facilities on Indang art. Data validity is done by triangulation.

Data were analyzed by ethnography, i.e determining the object, determining the domain analysis, determining the focused analysis and component analysis as well as the cultural theme. The data is then reduced and tested through analysis by interpretation of the researcher based on the theoretical references and problems that have been established.

\section{FINDING AND DISCUSSION}

The researchers observed that currently Indang's art has been increasingly rarely used for public entertainment activities. Researchers see there are various problems related to the lack of people's desire to use Indang art as a means of entertainment. It is very clear is caused because the art of Indang has not been able to meet the desires of the taste of today's society, because there is no match between the taste of society with the visual form of Indang art.

As Ade Suhandra points out, traditional Indang art is rarely used to entertain the public in general, but Indang art is still used as part of traditional events, or a complementary means for traditional ceremonies, and as entertainment on the alek nagari course. Apart from the event alek nagari Indang art very rarely used to entertain the public in general. Thus the art of Indang is used in certain activities and certain times only. This means that Indang art is not used as a means of public entertainment in general, including also for the entertainment of tourists, either in star hotels or public entertainment stage.

The Indang art now viewed by the community has no appeal to be used as a means of entertainment. Indang art is considered an outdated art form, so the traditional art performance of Indang has not been able to meet the artistic taste of Padang Pariaman society today. In turn, Indang art becomes an art that is marginalized by the community of its own supporters.

The condition of Padang Pariaman community that began to mingle with the outside community, so that the community received various insights about the arts from outsiders. This condition has changed the mindset of the Padang Pariaman community towards the arts. As expressed by Tondo (2009: 278), that with the mixing of indigenous peoples with migrants, there will be cultural dialogue between them. The results of this dialogue will change the mindset of some people to the local arts. This can be seen from the less popular case of art Indang for use by the community as a means of entertainment today. 
Based on information from Juni Amri, that the increasing insight Pariaman art community today, impact on the wishes or tastes of new people also to the local arts. The people of Padang Pariaman district now prefer the new artwork. The influence of these tastes is caused by the cross culture in Padang Pariaman society, because Padang Pariaman area is the crossing of migration path from Bukit Tinggi city to Padang, as well as close to Minangkabau international water port. The impact of cross-cultural is the occurrence of cultural dialogue of immigrants with indigenous communities, and will have an impact on the original art performances of the area.

Surianta (2017: 9) says that traditional art tends to be marginalized by the support community, as the society is contaminated with the new art. New art has a more recent innovation value than traditional art, because traditional art is viewed as outdated or outdated art. Such cases are present in many areas in Indonesia such as in Bali with traditional music cases, and this is true now in the context of Indang art in Padang Pariaman district.

Along with that, Rafiah said that society's response to traditional Indang art is more likely to undermine the artistic values of the arts. The public views that the art of Indang is less relevant to the taste of art of today's society. The community considered that art of art is art for people who adhere to the old or old culture, which is analogous to the traditional society. While today, the people of Padang Pariaman district think they have advanced in the culture, so the art they want must also advance in various ways. They view that art is a representation of the civilization of society in his day, therefore the cultural values of society will be reflected from the art produced by the people of that era.

As Indrayuda (2016: 146) says art like Minangkabau dance is a means of publication and expression for the cultural values contained in the life of the community owner. Therefore, through the contemporary dance of Minangkabau creations, the artist's creator begins to represent the values again. The impact of these representations is predicted to be a means of preserving and preserving the values of Minangkabau local cultivation, both for present and future society. And in fact the chill of society is the renewal of art Indang in the form of art more modern Indang. As what Indrayuda said, that creative dance creations and Indang will be liked by the community, and Indang or dance creations will remain an agent for the preservation of local values of Padang Pariaman community for the future.

In reality, Indang traditional artists are reluctant to develop the art in a new form. In turn the community marginalizes Indang art in its life, as a means of community entertainment. This causes Indang art is referred to as peripheral art, so art of Indang is only used by people who have understood ancient culture. This community response is very influential on the position of Indang art as one of the means of public entertainment in Padang Pariaman district.

In fact the traditional Indang art that is used today, visually and the procession of the show has not changed with Indang art that developed in 1970 to 1980 in Padang Pariaman. Indang artist community is very strict to maintain the essence and substance of Indang art, so the value of authenticity of Indang art can survive until now. But the disadvantage is that the public responds poorly, so the traditional Indang is rarely used for public entertainment.

A work of art that is interesting and has entertainment value is a work of art whose form and structure are dynamically arranged. In addition to dynamic, also has an artistic and innovation value. This means that artwork that appeals to today's society is an art that contains elements of innovation in various ways. Like dance, music and theater, if the art is included in the context of entertainment, then the artwork must contain entertainment value, but the entertainment value must always be new, in accordance with the time (Indrayuda, 2013).

Andriani (2012: 202), said that traditional art is the identity of a tribe. In some areas, they try to maintain the local arts, which have an impact on the strength of their cultural identity. Therefore, the Minangkabau community in the nagari retains its traditional arts as it preserves its cultural identity. Thus, the cultural behavior undertaken by the Padang Pariaman district community against the original values of Indang art to date is to introduce and maintain their identity. The rewards of the cultural behavior of the traditional art owner such as the Indang have received an unfavorable response for some people. People who respond poorly are the people of a group of reformers in the performing arts. They consider that Indang art is not only a cultural identity and a community, but it should also be used as a valuable entertainment means.

The general public responds to the problem of Indang art performance structures that are too loose, and the structure is less aesthetically connected between one with the other. The public judges often the structure of Indang art performance is not well structured, so often repetition on certain parts of the structure. In addition, there is no really climactic part of the Indang performance structure, which is being responded by the entertainment art consumer. In turn, these consumers marginalize Indang art from the entertainment arts market in Padang Pariaman regency.

Sari, K. M., Asriati, A., and Darmawati (2013) say that the structure can be interpreted as a unit of relationship between the parts contained in an organization of art form, such as dance, theater and music. The structure is contained in the overall relationship of the artwork. Good relationship arrangement is a relationship that is interconnected with neat, and contains harmony between one another.

Referring to the opinion Sari, Asriati, and Darmawati, the fact the public responded that the structure and shape of Indang art less well structured. The arrangement of relations arranged in Indang art performance is less intertwined between one part and the other with harmony. In addition, the relationships do not build a dynamic, dramatic part, so the show can mesmerize or hypnotize the audience. In the value of entertainment, the existing structure in Indang art has not been able to create a spectacular power to the audience, so that the audience has not been entertained by the art of Indang traditional. 
The Padang Pariaman community has assumed that the quality of traditional Indang art is irrelevant to the taste of today's society. People think it should be an entertainment commodity art Indang must be attractive, demonstrative, and entertaining. According to the general public art of Indang still has not changed in accordance with the wishes of the taste of today's society. In the end, the art of Indang is marginalized by society. The Padang Pariaman community responded negatively to the Indang art performance. this has an impact on the increasing rarity of Indang art used in public entertainment events today in Padang Pariaman district.

Sutiyono (2010: 5) said that the result of the show attraction of art work from the entertainment industry group has given a negative impression to the attractions of traditional performing arts as tour packages. The problem is that the attractions of art produced by the entertainment industry group are oriented to the value of today's tastes of art, which are attractive, dynamic, demonstrative, and long-winded. Along with that, Desfiarni (2013) says that most local people in Minangkabau or West Sumatra are still holding strong traditional values, so the community is difficult to accept change. Therefore, the artwork of this tradition is less desirable by the community as an entertainment commodity today.

Rafiah in his interview with researchers on March 28, 2017 in Pariaman, said that in the form and structure of Indang art that is shown, it looks very less variation, so that there is a repetition of the part within the structure of the exhibition. In turn this repetition becomes the weak point of the aesthetic value of Indang performances for today's society.

In addition, structural issues are also inconsistent in defining the phases or sections to be repeated in the performance. Indang art structures consisting of 4 parts of the prologue or introduction, the beginning, the climax and completion, but the climax is often not a climax. Many traditional Indang art performances today in Padang Pariaman have no climax, so it is difficult to tell which one is the center and which part of the projections. Therefore, Indang's show is less interesting to be an entertainment industry commodity. The reality is the public's response to Indang's current art performance in Padang Pariaman district.

Mansyur (2016: 27) said that the aspect of form is very important to be noticed by a creator artist, because in dance that first seen by the audience is choreography. Choreography can not be separated from the shape and structure of a dance performed. Therefore, a work of dance should be packaged with good choreography, because the works of art performances such as dance and theater that is enjoyed is visual. Visual then leads the audience's inspiration and imagination on understanding the value and meaning of the artwork. Unlike Cauto and Indrayuda (2013: 181), the performing arts are visual art, so artwork such as art of Indang must be able to interact with the audience as a connoisseur. If the art fails to interact, then the artwork will be excluded from the life of the community. Sociologically artworks should be subject to the circumstances of the times and tastes of the people who use them.

In fact Padang Pariaman society responded to traditional Indang art performance as an established art. In turn Padang Pariaman society increasingly marginalize the existence of art Indang as a means of public entertainment. Today traditional art Indang survive with its identity, and is still active in a limited scope, but in general people rarely use the arts as a commodity entertainment industry today in Padang Pariaman and in the region of West Sumatra.

\section{CONCLUSION AND RECOMMENDATION}

Community responses and views on traditional art nowadays have influenced the existence of Indang's art in the life of the community, especially the community of art entertainment service users in Padang Pariaman. Various responses such as the assessment of the shape and structure of Indang art, the way the show to the packaging as a whole. This response is done by the community because they feel less satisfied with Indang art performances that are not attractive, not demonstrative, and less entertaining.

The impact of these negative responses, influences on the development and sustainability of Indang art in community life in Padang Pariaman. In turn, the community marginalized the existence of traditional Indang art in the context of the interests of tourism and entertainment industry. Thus, people rarely use traditional Indang as a means of entertainment today in the community Padang Pariaman district.

Things that need to be noticed by artists and artists of traditional Indang is now a revamping. That is, the traditional artists need to open up, increase knowledge, and conduct cross-sector talks between academic artists, and professional artists, to gain knowledge and experience in the context of choreography. Another thing that is, it is suggested to the traditional artist or the owner and manager of Indang art, to need to adjust to the flow of changes that occur in the vicinity, so that in the future Indang art performance is not arid and become more qualified.

\section{References}

Andriani, T. 2012. Pantun Dalam Kehidupan Melayu (Pendekatan historis dan Antropologis). Jurnal Sosial Budaya, 9(2), $195-211$.

Cauto, Nasbahry, dan Indrayuda. (2013). Pengantar Sosiologi Seni. Padang: UNP Press

Desfiarni, D. (2013). Tinjauan Estetika Tari Piriang Jorong Limau Sundai Pasir Talang Solok Selatan. Humanus, 12(2), $120-129$.

Ediwar. 2010. Kesenian Indang dalam Konteks Budaya Rakyat Minangkabau. Jurnal Aswara, Jun 2010.

Efrida, E. (2016). Toleransi Masyarakat Minangkabau Terhadap Peran Perempuan dalam Aktivitas seni Budaya. Gelar, 7(2).

Efrida, E. (2016). Estetika Minangkabau dalam Gerak Tari Bujang Sembilan. Ekspresi Seni, 18(1).

Hardi, H. (2015). Karakteristik Karya Tari Syofiani dalam Berkreativitas Tari Minangkabau di Sumatera Barat. Ekspresi Seni, 17(1). 
Indrayuda, I. (2017). The Existence of Local Wisdom Value Through Minangkabau Dance Creation Representation in Present Time. Harmonia: Journal of Arts Research and Education, 16(2), 143-152.

Indrayuda, I. 2012. Eksistensi Tari Minangkabau dalam Sistem Matrilinial dari Era Nagari, Desa dan Kembali ke Nagari . Padang: UNP Press.

Indrayuda. 2013. Tari Sebagai Budaya dan Pengetahuan. Padang: UNP Press.

Kamal, Z. (2012). Eksistensi Seni Pertunjukan Luambek dalam Kehidupan Masyarakat Nagari Kepala Hilalang Kecamatan 2 X 11 Kayu Tanam Kabupaten Padang Pariaman.. Wacana Etnik, 3(1), 45-70.

Mansyur, Herlinda. (2016). Cahaya-cahaya yang Memudar. Laporan Seni Pertunjukan tidak dipublikasikan. Padang: FBS UNP.

Sari, K. M., Asriati, A., \& Darmawati, D. (2013). Struktur Gerak Tari Tupai Jonjang Di Kanagarian Lumpo Kecamatan IV Jurai Kabupaten Pesisir Selatan. Jurnal Sendratasik, 2(1), 65-72.

Subagyo, H. (2016). Visualisasi Garap Cerita dan Struktur dalam Tari Wireng di Mangkunegaran. Greget, 9(1).

Surianta, I. N. (2017). Marginalisasi Gamelan Batel dalam Seni Pertunjukan Wayang Kulit di Desa Sibanggede, Kabupaten Badung. Jurnal Ilmu Agama dan Kebudayaan, 15(01).

Sutiyono, S. (2010). Manajemen Seni Pertunjukan Kraton Yogyakarta Sebagai Penanggulangan Krisis Pariwisata Budaya. Bahasa dan Seni, 38(2).

Tondo, H. (2009). Kepunahan Bahasa-Bahasa Daerah: Faktor Penyebab dan Implikasi Etnolinguistis. Jurnal Masyarakat dan Budaya, 11(2), 277-296.

Vortixa, O., Agustina, A., \& Nursaid, N. (2012). Struktur Lirik Nyanyian Indang di Nagari Kuranji Hulu Kecamatan Sungai Geringging Kabupaten Padang Pariaman. Pendidikan Bahasa dan Sastra Indonesia, 1(1), 565-573. 